\title{
A long-term bibliometric analysis of journals influencing management accounting and control research
}

\author{
Marit Terese Balstad ${ }^{1} \cdot$ Terje Berg $^{2}$
}

Published online: 25 July 2019

(c) The Author(s) 2019

\begin{abstract}
This paper explores which journals publish management accounting research and which sources are most cited in these journals. We apply bibliometric methods based on citation data from Web of Science and Scopus. Quantitatively, we examined the boundaries of management accounting by analysing 506,753 and 1,075,838 cited references from each respective database in the timespans 1945-2018 and 19602018 and found that the five most cited journals represent $6.5 \%$ and $4.7 \%$ of the total citations. The most cited journal in both Web of Science and Scopus is AOS, followed by $M A R$. The findings are discussed in light of diversity, and the article will claim that the boundaries of management accounting research are not subject to severe constraints. Google Scholar was initially chosen alongside Web of Science and Scopus, but, among other challenges, Google Scholar does not provide comparable citation data. Therefore, issues concerning using citation data and databases are also thoroughly discussed.
\end{abstract}

Keywords Management accounting $\cdot$ Bibliometrics $\cdot$ Big six $\cdot$ Journals $\cdot$ Citations · Web of science $\cdot$ Scopus $\cdot$ Google scholar

JEL Classification M49

Terje Berg

terje.berg@ntnu.no

Marit Terese Balstad

marit.t.balstad@ntnu.no

1 Technology Library, Norwegian University of Science and Technology, 7491 Trondheim, Norway

2 NTNU Business School, Norwegian University of Science and Technology, 7491 Trondheim, Norway 


\section{Introduction ${ }^{1}$}

A substantial amount of management accounting research based on journals has seen the light of day. Journals included in these studies are often labelled as 'internationally recognized journals' (Roberts 2018, p. 76), the 'big six' (Salterio 2015, p. 153), 'highly valued' (ter Bogt and van Helden 2012, p. 266), 'top-tier' and 'the majors' (Swanson 2004, p. 223), 'prominently' (Hesford et al. 2007, p. 5), 'six leading journals' (Luft and Shields 2007, p. 27), 'ten leading journals' (Malmi 2016, p. 31), 'top accounting journals' (Oler et al. 2016, p. 63) or 'elite journals' (Beets et al. 2015, p. 316). Notwithstanding, journals (Lukka 2010; Malmi 2010; McCarthy 2012; Merchant 2010) and journal rankings (Sangster 2015; Guthrie et al. 2019) are pointed to as obstacles to more prospering accounting research. Indeed, the labels characterizing the journals are often taken for granted or merely given a superficial explanation. For instance, Hesford et al. do not justify why the (ten) selected journals 'represent outlets in which management accounting research has been prominently published' (2007, p. 5). Although we acknowledge that Swanson states that "the definition of "top-tier journals" is somewhat arbitrary and can affect the outcome' (2004, p. 229). This point is also stressed by Bonner et al. (2006): ‘[d]etermining the most influential journals in any field can be a contentious exercise; this is certainly the case in academic accounting as well' (p. 663).

Quite a few studies depart from Brown and Gardner (1985), who studied the articles cited by 545 articles written by accountants that appeared in The Accounting Review, Journal of Accounting Research, Accounting, Organizations and Society, and/or Journal of Accounting and Economics between 1976 and 1982, and Bonner et al. (2006) and their review of 16 articles ranking academic accounting journals. Bonner et al. (2006) used a sample in which all journals were subjectively selected.

The purpose of this paper is to quantitatively examine the boundaries of the scholarly field of management accounting represented by journals and the citations herein, and hence illuminate whether management accounting research within such a context seems to be lacking diversity. Our aim is to increase the knowledge on the use of citation data from the commercial databases Web of Science (WoS), Scopus, and Google Scholar (GS). We do this by answering the following questions: (1) which journals are the most cited in international citation databases within the field of management accounting, (2) are citation data from these databases a suitable means for ranking journals within the domain of management accounting? We apply bibliometric methods to avoid restricting the scope of management accounting

\footnotetext{
1 Thanks to the participants at the 13th Annual Conference for Management Accounting Research (ACMAR), 10-11 March 2016 and in particular Professor Dr Marco Reimer for his insightful comments and Professor Dr Utz Schäffer for introducing us to the German literature on the topic. Thanks to participants at the 10th Conference on New Directions in Management Accounting, Brussels, Belgium, 14-16 December 2016, in particular Professor Wim A. van der Stede. Especially, thanks to the two anonymous referees for challenging questions and remarks that have substantially improved the paper and the editor, Professor Dr Thomas Günther, for encouraging comments. Finally, thanks to Senior Researcher Ph.D. Nees Jan van Eck and Professor Dr Ludo Waltman both at Leiden University for kind advice regarding the use of VOSviewer. All remaining shortcomings are of course the sole responsibility of the authors.
} 
research to pre-specified journals. To the best of our knowledge, this is the first bibliometric analysis of three databases in the field of management accounting. We find a broad variety both of journals publishing management accounting research as well as these articles' cited sources.

Our study contributes to the literature in two ways: First, we challenge the view that management accounting is stagnant (Moser 2012) and suffering from lack of diversity (Hopwood 2008). We find a notable amount and variety of cited sources, particularly from adjoining disciplines such as management science, management, and strategic management.

Second, we find that only three of the often acknowledged 'big six' (Salterio 2015) are top ranked. Moreover, particularly in Web of Science, we find German journals, especially Zeitschrift für Betriebswirtschaft (ZfB), dominating the decades up to the 1980s, though disappearing thereafter, possibly due to lack of database indexing. Yet, the Anglophone journals are by far dominating. There is also a shift towards open access journals. This is important because journals and their citations represent a major part of the body of knowledge that constitutes a scholarly field. By studying the development over approximately 60 years, we add knowledge about the domain for publishing management accounting research over time. Even though we challenge the subjective selection of journals, we are non-biased regarding whether qualitative or quantitative methods are 'better' for ranking journals and if journals should be subject to ranking at all. Indeed, we are facing a possible paradox. Our intention is not to rank journals as such, even if we are making rankings to illustrate our case.

The study also brings insight to substantial issues that researchers should be aware of when databases are applied as a point of departure for citation analyses and research evaluation. This is relevant because more and more researchers' tenure, promotion, and research grants are subject to journal rankings such as the Academic Journal Guide (AJG) and Financial Times Research Rank (FT50). AJG for instance is, according to their homepage, 'informed by statistical information relating to citation.'

The rest of the article is organised as follows. First, we position the article within the literature. Then, we outline the method applied, including data collection, and justification of the search terms applied. We then thoroughly discuss the challenges this method holds, as well as why Google Scholar was expelled from further analysis. Thereafter, we present and discuss our empirics before we close the article with some suggestions for further research.

\section{Literature review}

\subsection{Diversity in management accounting research}

We position this paper within the literature exploring, explaining, and problematising the boundaries and scope of business schools' scholarly fields in general and management accounting in particular. More specifically, we depart from the research on the use and application of journals as a focal point and particularly 
the debate on diversity, see for instance Gendron (2008, 2018), Annisette et al. (2018), and Endenich and Trapp (2018). Diversity can be viewed as the application of different methodological angles and theoretical lenses, conceptual or empirical research approaches, as well as variety in the topics themselves. In the context of this paper, diversity is related to the scope of journals publishing management accounting research as well as these articles' sources. Moreover, we belong to the strand of researchers who believe that academic diversity is for the benefit of research itself as well as society at large.

One strand of this literature is concerned with academic diversity. For instance, Macdonald and Kam (2011) discuss the lack of diversity within management research in general. Their conclusion is that publication in the most highly ranked journals is highly skewed; just a few authors publish most of the papers. Based on this view, the proposition from Euske et al. (2011) that the control literature shows tendencies towards tribalism between management and accounting researchers should be of no concern for accounting researchers. If management research is skewed in a negative way, as claimed by Macdonald and Kam (2011), accounting potentially loses little by not drawing on the management literature. On the other hand, even being skewed, some or all of these papers may be of the highest quality, and thus they may enhance management accounting research. Nevertheless, Euske et al. (2011) call for more diversity of methods and theoretical frameworks in accounting, because it would allow for more advances in the field. In management accounting, Hesford et al. (2007) reveal two distinct networks of researchers: those publishing in Accounting, Organizations and Society $(A O S)$, and Management Accounting Research (MAR), and those publishing in eight 'major' North American journals. Hesford et al. (2007) speculate that the relative paucity of major advances in the field of management accounting may be due to disciplinary boundaries between these two networks. Interestingly, this is the opposite of Lukka and Kasanen's (1996) prediction that the 'polycentric oligarchy' could remove institutional barriers to the knowledge production process and open it up to a greater variety of research approaches.

Contrary to the claims of tribalism, yet possibly confirming the lack of diversity in the perceived leading journals, Summers and Wood (2017) state: 'For some topic areas and methodologies, articles published outside of the top journals regularly have more impact on the profession than articles published in the top journals [in accounting]' (p. 117). According to Salterio (2015), there has been limited growth of management accounting research in the 'top general interest' accounting journals. He claims that this is due to the lack of a globally acknowledged top niche journal in management accounting. Beets et al. (2015) assess accounting journal quality based on departmental lists from 67 AACSB business schools and find that specialist journals are preferred, and journals predominantly oriented towards practitioners are not allocated too much prestige. This may be a paradox: specialist journals are preferred, but these journals are claimed to depart from a narrow range of methodologies and theoretical approaches. Yet indeed, selecting specialist journals might only be considered a problem as far as their topics are heading towards a dead-end street, something that is not necessarily is the case. 
Lachmann et al. (2017) study positivist management accounting research (PMAR) over four decades in 'nine leading accounting journals' and conclude that both diversity and validity have increased over time. Nevertheless, they also conclude, with reference to Baldvinsdottir et al. (2010), that the range of topics researched has become narrower, focusing more on control issues such as social implications more than technical details, i.e. the accounting techniques themselves (for instance costing systems and budgeting). Also within the management control literature, the technical controls, such as procedures, are rarely seen (Tessier and Otley 2012). Interestingly, Herschung et al. (2018) find a large and diverse literature within empirical management accounting research. However, replication studies other than their own are scarce, and Summers and Wood (2017) claim that such studies are not particularly attractive in 'top' accounting journals. The absence of replication studies may be somewhat surprising within a scholarly field lacking a unified theory and perhaps aiming at establishing an accepted body of knowledge.

Beyond the Anglophone research community, however, the picture seems to be somewhat different. Binder and Schäffer (2005), Schäffer et al. (2006), and Meyer et al. (2008) apply bibliometric methods to six Germanic academic journals, four practitioner journals, as well as four academic journals in the English language. They find that the area of management accounting has developed significantly. The focus has moved from cost accounting to techniques such as target costing and the balanced scorecard. Meyer et al. (2008) show that German accounting scholars are inspired by English-language journals to a larger and larger extent, yet the transfer of knowledge seems to be a one-way street. While German scholars adopt ideas from the English-speaking community, the opposite is the case far less frequently. In these veins, Raffournier and Schatt (2010) study whether or not academic journals fairly reflect European accounting research. They compare presentations at the European Accounting Association's annual conferences from 2003 to 2005 to articles published in 18 accounting journals. Although they primarily study financial accounting, their conclusion is that language barriers prevent scholars from nonEnglish-speaking countries from publishing in Anglophone journals.

\subsection{Citation analysis in bibliometric studies}

Bibliometric methods are statistical analyses used to examine scientific publications, and citation analysis constitutes a significant part of bibliometrics. A citation, in this paper, is understood as an entry in an article's reference list. The foundation of citation analyses is the belief that a citation is a valid and reliable indicator of a publication's influence on, and contribution to, a discipline (Garfield 1979, p. 372; White 2012, p. 1012). According to Borgman (2007, p. 70) and Kärki and Kortelainen (1998, p. 66), citations are very important to a publication's legitimacy, and '[w]e know that high citation rates correlate with peer judgements about scientific excellence and the importance of contributions' (Garfield 1979, p. 372). 'The most common means of bestowing credit and recognition in science is via citations', as Cronin (1984, p. 2) puts it. 
There are indeed some problems with using citations as a measure. According to Fleck (2013), '...the emergence of the impact factor was a completely incidental result of Garfield's animus shovelling around the huge amounts of data stored in the then rare mainframe computers of his Institute for Scientific Information (ISI)' (p. 333). The main criticism is that citations are an imprecise measure of a publication's quality. We cannot know for sure why a publication is cited or what role the citation has (Cronin 1984, p. 29; Kärki and Kortelainen 1998, p. 67; Moed 2005, p. 80). Meyer et al. (2018) analyse what drives citations considering universalism (article content) and particularism (author characteristics). Based on a three-step regression of articles published in five 'top' 2 accounting journals, they urge caution against the use of citation counts as an indicator of quality. In these veins, Aksnes et al. (2019, p. 12), in a thorough review of the basic concepts and theories of citations, conclude that "citations reflect-with important limitations-aspects related to scientific impact and relevance, but there is no evidence that citations reflect other key dimensions of research quality".

Researchers cite friends as well as themselves, and a publication of low quality may obtain many citations due to criticism of the publication; negative citations (Garfield 1979, p. 361; Cronin 1984, p. 30). There are also examples of journals imposing on authors to cite articles from the given journal to increase their own number of citations (Kärki and Kortelainen 1998). Further, the bibliography may be inexhaustive; classics considered conventional wisdom (i.e., a body of ideas and explanations generally accepted as true within a field) are not cited, or references are forgotten or deliberately omitted for instance due to word count or other reasons. A study by Macroberts and Macroberts (1989) finds that authors cited only a third of the publications that had influenced their research.

One issue is the language bias in the data; mainly outlets in the English language are indexed. English-language journals constitute most of the scientific publications and enjoy without doubt the greatest international impact (Moed 2005, p. 78). English is the lingua franca of science in general and management accounting in particular (Evans 2010). Publications in other languages rarely reach outside their own language area, and even though the influence within their domain can be considerable (Evans 2010), these will most probably be missing in the present study.

Another factor is citation databases that only include citations in articles as monographs are not indexed. Moed (2005, pp. 126-129) finds that in subjects such as accounting, economics and finance, $56-66 \%$ of the references are based on journals; the rest are left to monographs and other sources. Moed (2005, pp. 126-129) further finds that WoS includes 76-83\% of the journal citations in journal articles within the subject fields of accounting, finance, management, and economics.

\footnotetext{
2 These authors are among the few using quotation marks, thus signalling that the notion of a 'top' journal is not straightforward.
} 


\section{Method}

\subsection{Data collection and keywords}

There are only three providers of international citation data: Web of Science, Scopus and Google Scholar, all of which are commercial. In this paper, we aim at finding the journals most cited in research under the umbrella of management accounting. To do this, we first identify management accounting research by searching databases for articles based on selected keywords. Then, these articles' bibliographies are analysed. We withdraw the sources being cited from the bibliographies; they are the foundation for the final journal ranking. Source in this context means journals.

WoS (formerly The Institute for Scientific Information (ISI)) was established in 1960 and is now owned by Thomson Reuters. Its indices go back to 1945 . Scopus was established by Elsevier in 2004 and covers more journals than WoS, but its indices only go back to 1960. It is important to note that coverage for each journal is not necessarily complete. For instance, Scopus indexes all volumes of $A O S$ and MAR, while WoS only indexes MAR from 2008 and AOS from 1981. GS is Google's academic search. In addition to indexing journals, GS also indexes non-scholarly documents like government reports and student theses. However, there is no transparency regarding exactly what GS covers.

The first challenge is to define management accounting. As Robert Scapens stated in his final editorial in MAR: (1) 'We deliberately avoided defining 'management accounting' as this could restrict the development of the journal.' (2) 'I have taken the view that the scope of management accounting is defined by the papers which are in the journal.' (Scapens 2014: 246). Therefore, in this article, we depart from an understanding of management accounting in the veins of the German Controlling, the Swedish Ekonomistyrning, and the Danish and Norwegian Økonomistyring. These concepts are much broader than management accounting and embrace performance management, management control, and performance measurement (see for instance Schäffer (2013), Günther (2013) and Berg (2015)). In addition, the terms management accounting and management control are sometimes used interchangeably (Chenhall 2003). Furthermore, Ferreira and Otley (2009) use the construct of performance management systems as superior to and embracing management control and hence management accounting as well. Thus, research under the heading performance management may as well be management accounting. Also, management control has numerous analytical conceptualizations (Strauss and Zecher 2013; Berens 2014). The title of the present journal itself, also indicates that management control should be included. Furthermore, we include performance measurement, both because it is a part of the CIMA Official Terminology, but also because the journal Management Accounting Research dedicated a special issue to the topic (MAR 25(2)). Moreover, according to Franco-Santos and Otley (2018: 696), performance management systems involve performance planning, measures, targets, incentives and other means of control. Indeed, we also acknowledge that performance management and performance measurement have no straight-ahead interpretation, see for instance Bourne et al. (2018). 
Table 1 Keywords (search terms)

\begin{tabular}{|c|c|}
\hline Keywords & $\begin{array}{l}\text { Management accounting } \\
\text { Managerial accounting } \\
\text { Managerial economics } \\
\text { Management accounting and control } \\
\text { Cost management } \\
\text { Cost accounting } \\
\text { Management control } \\
\text { Performance management } \\
\text { Performance measurement } \\
\text { Business control } \\
\text { Business controlling }\end{array}$ \\
\hline
\end{tabular}

As claimed above, in German-speaking countries 'controlling' is widely accepted as a general label for management accounting and management control systems (Günther 2013). However, searching Google Scholar for 'controlling' returns 4.90 million hits, including articles in Physical Letters and Nature about topics far from management accounting. Searching 'controller' returns 4.88 million hits, many related to micro-controllers, i.e. a small computer or a single integrated circuit. Thus, we added the prefix 'business' as in 'business control' and 'business controlling'. We have excluded the personification, as for instance management accountants, business controllers, CFOs, or financial managers, as the use of titles may not be consistent and numerous.

One option may be to include terms such as 'budgeting', 'costings systems' or 'the balanced scorecard', which fits with reasons for applying management accounting justified by organizational economics (Samuel 2018). However, selecting terms at this level of detail may be a foolhardy exercise. As noted by Ax and Bjørnenak (2007), 250 (59.2\%) of the concepts listed in the 12th edition of Cost Accounting (Horngren et al. 2005) are new compared to those in the first edition (Horngren 1982). Which search terms to include, and which to exclude to get a good data set, is thus a central and challenging question. In this paper, we chose generic umbrella terms and not a system's type of use, level of sophistication, or organizational outcomes (Günther and Heinicke 2019). Yet, we acknowledge that where we draw the line for search terms will influence the outcome.

The eleven search terms are presented in Table 1:

We performed topical searches in the Science Citation Index Expanded (SCIEXPANDED) and Social Science Citation Index (SSCI) in WoS for the years 1945 through 2018, refining the search to articles only. In Scopus, we conducted document searches, also only covering articles published between 1960 and 2018. In GS, we also searched the selected terms for the time span 1945-2018. Including only full years makes searches reproducible. Yet, reproducing searches in GS is difficult as the index changes rapidly. 


\subsection{Issues regarding searching databases and downloading data}

The data collection is comprehensive, time-consuming, and there are several potential sources of error present. The searches conducted in WoS and Scopus will look for the search terms in the title field, the abstract field, and the keyword field. This kind of limited metadata search is not possible in GS; the only options are to search anywhere in the article or only in the title field and to include any kind of document found in the index, not only articles. The metadata quality in GS is simply bad, as demonstrated by Jacsó (2010) for instance.

Searching only the title field for our keywords in GS retrieved 15,500 articles; searching anywhere retrieved 17,300. As many articles do not use our search terms as part of their title, we chose to use the results from anywhere as a starting point, as this will include more relevant documents without too many irrelevant ones. In addition, when limiting the search year-by-year to identify the development of citations, we experienced a rather odd outcome. Limiting the search to the timespan 1945-2018 returned 629,000 articles, i.e. more than in searches not limited by years. In addition, the sum of year-by-year searches for 1945-2018 adds up to more than 260,000 articles. In addition, searching the eleven terms one by one, adds up to $1,962,120$. Yet, GS does not allow for more than nine search terms at the same time. This clearly demonstrates that GS should be used with the utmost caution in the case of controlled searches.

Indeed, the data quality of GS has been thoroughly criticised; see for instance Jacsó (2005, 2006, 2010). This, Aguillo (2012) argues, means that citation data from GS is not comparable to data from traditional bibliometric databases (WoS and Scopus). However, as Stuart (2014) says, GS 'should be seen as providing additional, complementary metrics' (p. 130) based on citations from more diverse publications or formats previously underrepresented in bibliometric analyses. In addition, Harzing and Alakangas (2016) found that all three citation databases 'provide sufficient stability of coverage' (p. 802) and include GS in their study. This and the fact that GS is very popular among researchers are reasons for including GS.

However, there are also issues regarding WoS and Scopus. Historically, storing data used to be expensive, therefore the data was compressed. This means, for instance, that journals are represented by abbreviations, but the use of abbreviations is not consistent or universal. For instance, we found 10 abbreviations representing the journal Strategic Finance in the WoS data set. Altogether, we found 36 journals with more than one abbreviation. There is no list of abbreviations available from the database providers, any abbreviations must be manually checked by the researcher.

To overcome this problem, we constructed one thesaurus file for each database to merge the data. By searching the abbreviations in the citation data source, the authors succeeded in verifying the titles. However, journal titles are not spelled consistently; for instance, 'organisation' and 'organization' are used interchangeably. Furthermore, some journals have changed their name several times over the years; Strategic Finance is on its sixth name since the 1920s. This is also considered in the thesaurus file. Nevertheless, we acknowledge that we have almost certainly overlooked some abbreviations in the current paper. 
We must also state that none of the databases is complete; each one represents only part of the available research. WoS and Scopus provide complete lists of what they index. This kind of transparency is not offered by GS. WoS and Scopus also manually control their metadata. What is especially important to us is that they provide keywords, both from the author(s) and their own. In this way, nonEnglish articles may be indexed with keywords such as management accounting. However, the adequacy is dependent on the indexer. WoS and Scopus also provide duplicate control, i.e. one article is counted only once. If GS finds the same article multiple places on the web, for instance at Research Gate, the institutional archive and the publishing house, one article may be counted three times.

Another challenge is the reliability of the specific searches. When searching for management accounting, do we get management accounting research? A topic search in WoS based only on management accounting returned 985 articles; a number itself very low. All but eight were placed within the field of management accounting upon manual inspection. The following quote illustrates that the method using search terms is not bulletproof: 'These deal primarily with the mechanisms and epidemiology of the disease, with papers dealing with depression management accounting for the fastest growing group of citation classics' (Lipsman and Lozano 2011, p. 39). For the other search terms and databases, we only randomly checked for this kind of incorrect indexing; a check that lead us to expel the term financial management (FM). Scopus returned 90,366 articles labelled FM, approximately twice the sum of the other keywords altogether. A random control revealed many irrelevant articles, especially medical ones. However, the same was not the case for Web of Science. In addition, we checked the most cited authors, all of whom made sense when it came to the area being studied (Kaplan, Chenhall, Simons, Neely, Otley, Langfield-Smith, Fornell, Eisenhardt, DiMaggio among others). Also, we extracted data for each of the search terms individually and compared them with the main search (the 11 search terms altogether). This allowed us to see whether some of the search terms had to be considered too generic.

It is possible to download citation data directly from WoS and Scopus. In WoS, the restriction is set to citation data from 500 articles per download. For us, this means downloading 28 different files to get all the data. In Scopus, the restriction is set to 2000 hits per download, and it is necessary to conduct multiple searches resulting in a maximum of 2000 hits. We did this by limiting the searches by time spans, requiring 26 searches/downloads to get the full data set.

To download data from GS, one must use secondary software, as GS is lacking an application programming interface (API). We applied Publish or Perish (PoP) (Harzing 2007); another alternative is programming in Python (Stuart 2014, p. 130). In GS, i.e. PoP, the download restriction is set to the 1000 most cited articles, which makes it impossible to download a full data set. Furthermore, neither PoP nor Python programming include the citation data we need in their available downloads. In addition to these shortcomings, Jacsó finds that GS is 'especially inappropriate for bibliometric searches, for evaluating publishing performance and impact of researchers and journals' (2010, p. 175). As a result, GS was excluded from further analyses. 
Table 2 Overall empirical findings

\begin{tabular}{lll}
\hline & WoS & Scopus \\
\hline No. of articles based on search terms & 12,014 & 42,925 \\
No. of entries in the articles' references' lists & 506,753 & $1,075,838$ \\
No. of unique cited sources in the articles above & 137,163 & 419,175 \\
Index $_{1}$-Average number of entries in the references (Line 2/Line 1) & 42.18 & 25.06 \\
Index $_{2}$-Average number of unique sources in the entries (Line 2/Line 3) & 3.69 & 2.57 \\
\hline
\end{tabular}

The data from WoS and Scopus were further analysed in a spreadsheet. Converting data can be a source to errors and omissions. Finally, we used the program VOSviewer to sum up the citation data, merge the journal data using the thesaurus files, and find the most cited sources effectively.

\section{Empirical findings}

The results from the data set clearly show that Scopus has a larger index than WoS (Table 2).

The number of articles in Line 2 is the number of articles adding up the overall journal ranking: WoS returns 12,014 articles based on the 11 selected search terms. These articles provide a total of 506,753 entries in their reference lists. In these reference lists, two or more articles could, for instance, be from Journal of Management Control. Thus, 137,163 discrete sources (journals, books, etc.) are identified, something that might indicate diversity in management accounting research. Scopus returns 42,925 articles interpreted as management accounting, and these articles include 1,075,838 entries from 419,175 sources in their reference lists.

To expand the picture of possible diversity, we created two indices. Index ${ }_{1}$ gives the average length of the reference lists. This is calculated as number of entries in the articles' references/number of articles based on search terms. The larger the number, the longer the bibliography. The second index aims at capturing diversity in the bibliographies and is calculated as number of entries in the articles' references/ number of cited sources. The smaller the number, the more diverse the bibliography, whereas a large number indicates the same sources being cited repeatedly. The figures for WoS and Scopus indicate consistency across the two databases. Index ${ }_{2}$ itself indicates diversity when it comes to reference lists, and Index ${ }_{1}$ and Index combined indicate that several journals, books, and other types of sources are present in the bibliographies. Hence, there are indications that published articles draw on a variety of previous research, in line with the findings of Herschung et al. (2018).

\subsection{Yearly distribution of articles}

In WoS, we find articles from every year from 1956 to 2018, but the years 1945-1946 and 1952-1953 are also represented: 


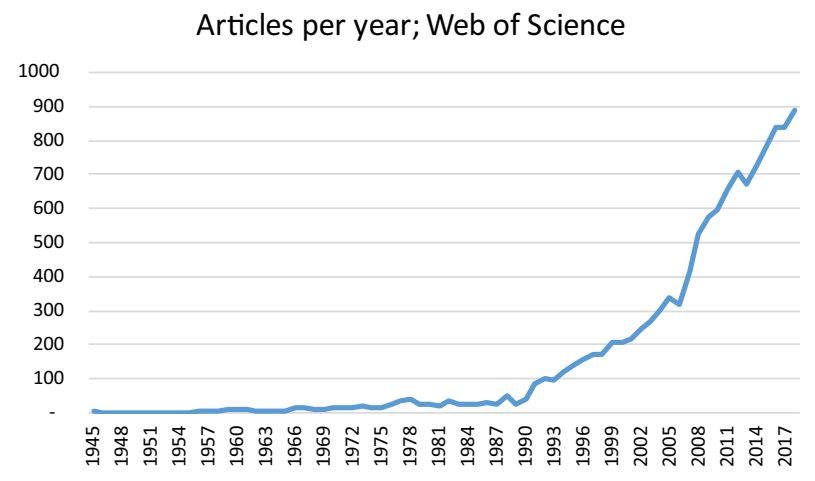

Fig. 1 Articles per year, WoS, 1945-2018

As Fig. 1 reveals, there is an increase in the number of articles around 1990, and another leap around 2008. In the years before, there is an even distribution of articles per year. Particularly interesting is the remarkable leap in the number of articles starting around 2008. This may be due to an increase in the number of publications, better indexing, or a shift in paradigms researched, but most of all the reason is that WoS expanded its coverage substantially in 2009. For instance, WoS began indexing Management Accounting Research in 2009 (Scapens 2014). It may also reflect that our chosen keywords are used more frequently. An increased focus on 'publish or perish' may also be observed over the last 20 years. As Card and DellaVigna (2013) find in their study of 'top' journals in economics, annual submissions nearly doubled from 1990 to 2012, yet the acceptance rate declined. This is also the case within management accounting (Scapens 2014). Some of the rejected articles may have been published in other journals than the ones indexed by WoS and Scopus. An increase in the number of articles written may also have fostered new outlets for these articles, and thus made possible an increase in research on management accounting.

Figure 2 shows the yearly distribution of articles in Scopus. The figure indicates a first shift in these data around 1976, a second around 1990, and a third around 2008. The second and third shifts are also present in the data from WoS. AOS began publication in 1976 and MAR in 1990 (both fully indexed in Scopus), which may explain the increase in the number of articles in these years. What happened around 2008 requires further analysis, although the previous paragraph offers some possible explanations, including the fact that Scopus was launched in 2004.

\subsection{Journals publishing management accounting research}

Regardless of database, we observe a substantial increase in the number of articles returning the keywords. This is in line with Lachmann et al. (2017) and Herschung et al. (2018). The 12,014 and 42,925 articles found in the respective databases are mainlypublished in the journals presented in Fig. 3. 


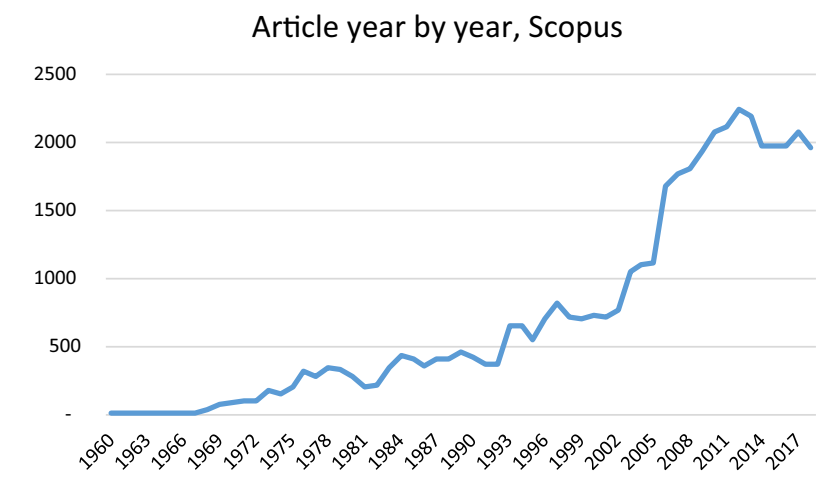

Fig. 2 Articles per year, Scopus, 1960-2018

Journals most frequently publishing the analysed articles, WoS

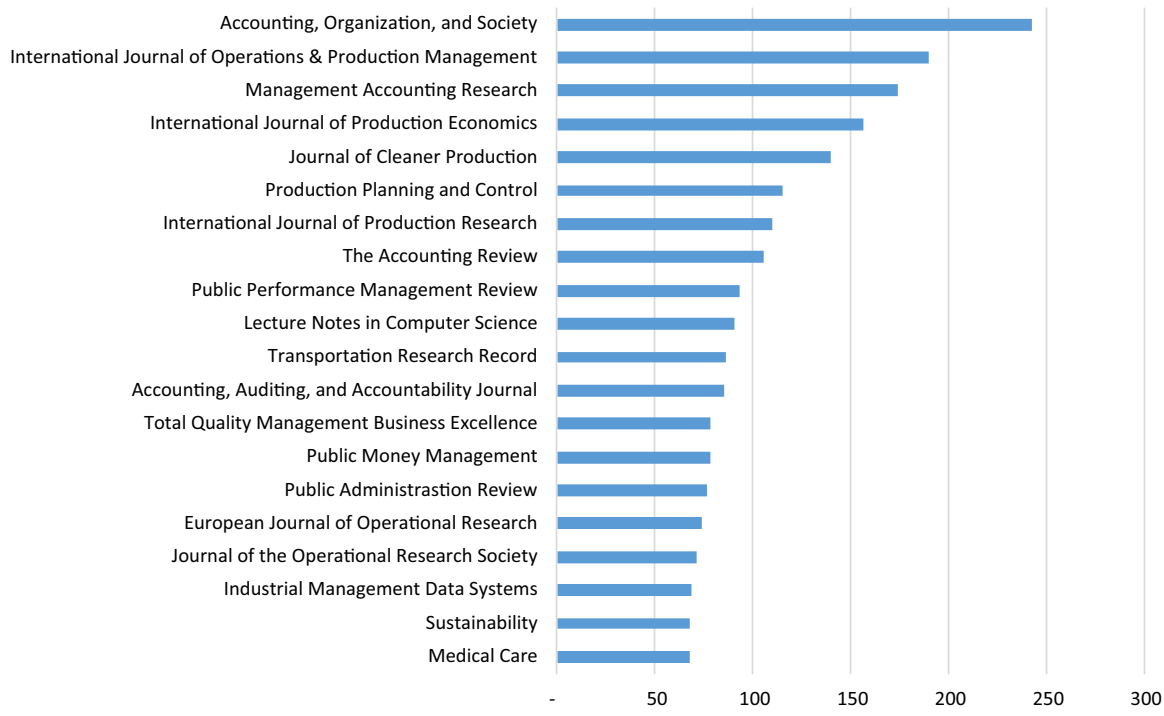

Fig. 3 Most frequent journals, WoS, 1945-2018

From the figure, we can derive quite a diversity with respect to the scholarly fields 'traditional' accounting, as well as informatics and health care.

The diversity of outlets is also evident in the results for Scopus, as can be seen in Fig. 4.

Interestingly, the open access journal PLOS ONE is the 9th most frequent journal in the sample. It is a journal that has been published since 2006 and particularly publishes within science and medicine. Ten journals are present in both Figs. 3 and 4 (listed in alphabetical order): (1) Accounting, Organization, and Society, (2) European Journal of Operational Research, (3) International Journal 
Journals most frequently publishing the analysed articles, Scopus

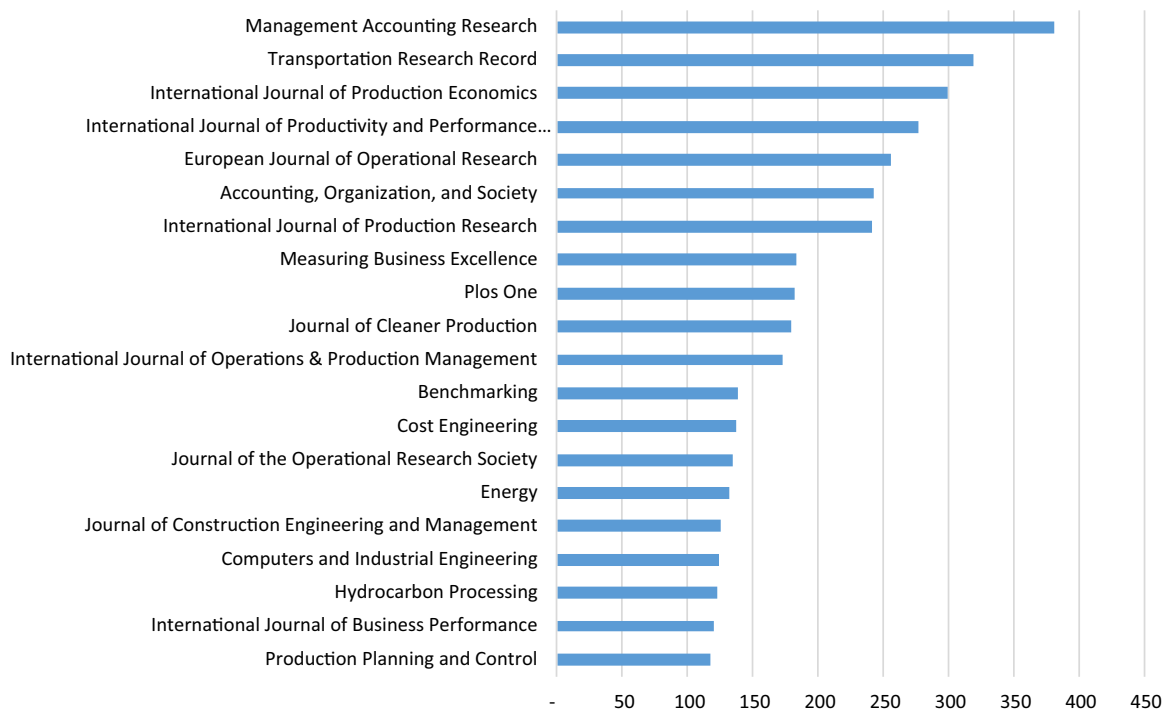

Fig. 4 Most frequent journals, Scopus, 1960-2018

of Operations and Production Management, (4) International Journal of Production Economics, (5) International Journal of Production Research, (6) Journal of Cleaner Production, (7) Journal of the Operational Research Society, (8) Management Accounting Research, (9) Production Planning and Control, (10) Transportation Research Record.

Overall, there seems to be a wide range of journals publishing management accounting research. As Summers and Wood (2017) claim, articles published outside the profession appear to have an impact on research within the profession. This may not be particularly surprising, as there is no unified corpus within management accounting. In addition, the diversity may reflect the findings of Binder and Schäffer (2005) and Schäffer et al. (2006), i.e. a significant development of the field of management accounting.

Table 3 indicates a shift in journals publishing research related to our keywords. This holds for both examined databases. Concerning WoS, two journals dominate until 1980: The Accounting Review and Zeitschrift für Betriebswirtschaft (ZfB, from 2013 Journal of Business Economics). AOS enters the scene in 1976 and is the main journal from 1980-2009, followed by International Journal of Operations and Production Management, succeeded by MAR from 2010 until today. The picture is different in Scopus. From 1960 until 1980, engineering journals were dominating. From then on, the more expected journals are present such as MAR, International Journal of Production Economics, and International Journal of Productivity and Performance Management. Common for the 
Table 3 Most frequent journals, WoS and Scopus, decade by decade

\begin{tabular}{|c|c|c|}
\hline & WoS & Scopus \\
\hline \multicolumn{3}{|c|}{ 1945-1959 } \\
\hline 1 & Zeitschrift für Betriebswirtschaft & $N / A$ \\
\hline 2 & The Accounting Review & \\
\hline 3 & Communications of the ACM & \\
\hline \multicolumn{3}{|c|}{ 1960-1969 } \\
\hline 1 & The Accounting Review & $\begin{array}{l}\text { Australian Journal of Agricultural } \\
\text { Economics }\end{array}$ \\
\hline 2 & Zeitschrift für Betriebswirtschaft & Engineering Economist \\
\hline 3 & Management Controls & Hospitals \\
\hline \multicolumn{3}{|c|}{ 1970-1979 } \\
\hline 1 & Cost and Management & Hydrocarbon Processing \\
\hline 2 & The Accounting Review & Chemical Engineering New York \\
\hline 3 & Zeitschrift für Betriebswirtschaft & TAPPI \\
\hline \multicolumn{3}{|c|}{ 1980-1989 } \\
\hline 1 & Accounting, Organization, and Society & Transportation Research Record \\
\hline 2 & Problems of Economics & Chemical Engineering New York \\
\hline 3 & American Journal of Hospital Pharmacy & Chemical Engineering Progress \\
\hline \multicolumn{3}{|c|}{ 1990-1999 } \\
\hline 1 & Accounting, Organization, and Society & $\begin{array}{l}\text { International Journal of Production } \\
\text { Economics }\end{array}$ \\
\hline 2 & $\begin{array}{l}\text { International Journal of Operations and } \\
\text { Production Management }\end{array}$ & Management Accounting Research \\
\hline 3 & $\begin{array}{l}\text { International Journal of Production } \\
\text { Economics }\end{array}$ & $\begin{array}{l}\text { European Journal of Operational } \\
\text { Research }\end{array}$ \\
\hline \multicolumn{3}{|c|}{ 2000-2009 } \\
\hline 1 & Accounting, Organization, and Society & Management Accounting Research \\
\hline 2 & $\begin{array}{l}\text { International Journal of Operations and } \\
\text { Production Management }\end{array}$ & $\begin{array}{l}\text { International Journal of Production } \\
\text { Economics }\end{array}$ \\
\hline 3 & Lecture Notes in Computer Science & $\begin{array}{l}\text { International Journal of Productiv- } \\
\text { ity and Performance Management }\end{array}$ \\
\hline \multicolumn{3}{|c|}{ 2010-2018 } \\
\hline 1 & Management Accounting Research & Plos One \\
\hline 2 & Journal of Cleaner Production & $\begin{array}{l}\text { International Journal of Productiv- } \\
\text { ity and Performance Management }\end{array}$ \\
\hline 3 & Public Performance Management Review & Journal of Cleaner Production \\
\hline
\end{tabular}

latest 9 years we studied is the Journal of Cleaner Production. This could be due to the generally increased interest for the topic that the journal's title indicates. The presence of PLOS ONE may not be surprising because the journal has published 200,000 articles as of September 2017. 


\subsection{Most cited journals according to WoS and Scopus}

The next step is finding the most cited journals, i.e. how the 506,753 and 1,075,838 citations are distributed among the 137,163 and 419,175 sources.

The five most cited journals according to WoS represent approximately $6.5 \%$ of the total citations (Table 4). The 10 most cited journals represent $10.3 \%$ of citations, and the 15 most cited journals cover $13.4 \%$ of the 506,753 citations. This indicates an enormous number of journals being cited in research on management accounting. This also indicates a diversity in input for management accounting research. However, in the vein of Meyer et al. (2008) and Raffournier and Schatt (2010), it indicates the dominant role of Anglophone journals as sources for management accounting research.

Table 5 reveals a smaller concentration in Scopus than WoS. The five most cited journals represent $4.7 \%$, the 10 most cited $7.0 \%$, and the 15 most cited journals according to Scopus cover $8.7 \%$ of the $1,075,838$ citations. This may be due to the far larger number of indexed journals.

Looking at the numbers decade by decade for WoS, we find a shift from Germanic journals and The Accounting Review to AOS and MAR particularly. Six journals appear more than once. AOS appears four times, while The Accounting Review, Zeitschrift für Betriebswirtschaft, and Harvard Business Review all appears three times. Finally, Zeitschrift für handelswissenschaftliche Forschung and Management Accounting Research are represented in two decades, yet in each end of the time frame. When it comes to Scopus, only three journals are represented in more than

Table 4 Most cited journals according to WoS, 1945-2018 (top 15 of 137,163 sources)

\begin{tabular}{llrr}
\hline$\#$ & Source & $\begin{array}{l}\text { Number of citations, } \\
\text { WoS }\end{array}$ & $\begin{array}{l}\text { Market } \\
\text { share" }(\%)\end{array}$ \\
\hline 1 & & 12,855 & 2.5 \\
2 & Accounting, Organization, and Society & 6955 & 1.4 \\
3 & Management Accounting Research & 4623 & 0.9 \\
& International Journal of Operations and Production & & 0.9 \\
4 & Management & 4370 & 0.9 \\
5 & Academy of Management Journal & 0.8 \\
6 & Harvard Business Review & 4324 & 0.8 \\
7 & Strategic Management Journal & 4165 & 0.8 \\
8 & Academy of Management Review & 4112 & 0.7 \\
9 & The Accounting Review & 3815 & 0.7 \\
10 & European Journal of Operational Research & 3625 & 0.7 \\
11 & International Journal of Production Economics & 3587 & 0.6 \\
12 & Public Administration Review & 3335 & 0.6 \\
13 & Management Science & 3252 & 0.6 \\
14 & Journal of Applied Psychology & 3118 & 0.5 \\
15 & Administrative Science Quarterly & 2968 & 13.4 \\
& Journal of Cleaner Production & 2675 & 506,753 \\
\hline
\end{tabular}


Table 5 Most cited journals according to Scopus, 1960-2018 (top 15 of 419,175 sources)

\begin{tabular}{llrl}
\hline$\#$ & Source & $\begin{array}{l}\text { Number of citations, } \\
\text { Scopus }\end{array}$ & $\begin{array}{l}\text { Market } \\
\text { share" }(\%)\end{array}$ \\
\hline 1 & & 18,000 & 1.7 \\
2 & Accounting, Organization, and Society & 11,959 & 1.1 \\
3 & Management Accounting Research & 8132 & 0.8 \\
4 & Harvard Business Review & 7234 & 0.7 \\
& International Journal of Operations and Production & & 0.5 \\
5 & Management & 5336 & 0.5 \\
6 & Management Science & 5119 & 0.5 \\
7 & Academy of Management Journal & 5110 & 0.5 \\
8 & The Accounting Review & 5065 & 0.5 \\
9 & European Journal of Operational Research & 4934 & 0.4 \\
10 & Strategic Management Journal & 4780 & 0.4 \\
11 & Academy of Management Review & 4580 & 0.3 \\
12 & International Journal of Production Economics & 3746 & 0.3 \\
13 & Administrative Science Quarterly & 3682 & 0.3 \\
14 & Journal of Management Accounting Research & 3184 & 0.3 \\
15 & Journal of Operations Management & 3121 & 8.7 \\
& International Journal of Production Research & $1,075,838$ & \\
\hline
\end{tabular}

one decade: Chemical Engineering New York, Harvard Business Review, and MAR. It is also worth noting that only AOS, MAR, and Harvard Business Review are the only journals being ranked 'Top Three' in both databases at some time (Table 6).

$A O S$ and MAR are the most cited journals in both WoS and Scopus. Twelve journals are common for WoS and Scopus. These are in alphabetical order: (1) Academy of Management Journal, (2) Academy of Management Review, (3) Accounting, Organization, and Society, (4) Administrative Science Quarterly, (5) European Journal of Operational Research, (6) Harvard Business Review, (7) International Journal of Operations and Production Management, (8) International Journal of Production Economics, (9) Management Accounting Research, (10) Management Science, (11) Strategic Management Journal, and (12) The Accounting Review.

Interestingly, only three of the 15 journals most cited on WoS and Scopus are also regarded as part of 'the big six' (Salterio 2015): AOS, MAR, and The Accounting Review. Hence, Contemporary Accounting Research, Journal of Accounting and Economics, and Journal of Accounting Research are not top 15 in our study. It is maybe not surprising to find Harvard Business Review (HBR) being cited so frequently in both the WoS and Scopus data; for instance, Kaplan and Norton articles on the balanced scorecard are frequently cited. However, $H B R$ is regarded in some circumstances as a practitioners' journal (Wilkinson 2016), and Beets et al. (2015) claim that practitioners' journals are not highly regarded in departmental ranking lists. 
Table 6 Most cited journals according to WoS and Scopus, decade by decade

\begin{tabular}{|c|c|c|}
\hline & WoS & Scopus \\
\hline \multicolumn{3}{|c|}{ 1945-1959 } \\
\hline 1 & Zeitschrift für Betriebswirtschaft & N/A \\
\hline 2 & $\begin{array}{l}\text { Hygiea: A Journal of Individual and } \\
\text { Community Health }\end{array}$ & \\
\hline 3 & $\begin{array}{l}\text { Zeitschrift für handelswissenschaftliche } \\
\text { Forschung }\end{array}$ & \\
\hline \multicolumn{3}{|c|}{ 1960-1969 } \\
\hline 1 & The Accounting Review & $\begin{array}{l}\text { Australian Journal of Agricultural } \\
\text { Economics }\end{array}$ \\
\hline 2 & Zeitschrift für Betriebswirtschaft & Engineering Economist \\
\hline 3 & $\begin{array}{l}\text { Zeitschrift für handelswissenschaftliche } \\
\text { Forschung }\end{array}$ & Hospitals \\
\hline \multicolumn{3}{|c|}{ 1970-1979 } \\
\hline 1 & The Accounting Review & Hydrocarbon Processing \\
\hline 2 & Harvard Business Review & Chemical Engineering New York \\
\hline 3 & Zeitschrift für Betriebswirtschaft & TAPPI \\
\hline \multicolumn{3}{|c|}{ 1980-1989 } \\
\hline 1 & Accounting, Organization, and Society & Transportation Research Record \\
\hline 2 & The Accounting Review & Chemical Engineering New York \\
\hline 3 & Journal of Accounting Research & Chemical Engineering Progress \\
\hline \multicolumn{3}{|c|}{ 1990-1999 } \\
\hline 1 & Accounting, Organization, and Society & $\begin{array}{l}\text { International Journal of Production } \\
\text { Economics }\end{array}$ \\
\hline 2 & Harvard Business Review & Management Accounting Research \\
\hline 3 & Administrative Science Quarterly & European Journal of Operational Research \\
\hline \multicolumn{3}{|c|}{ 2000-2009 } \\
\hline 1 & Accounting, Organization, and Society & Management Accounting Research \\
\hline 2 & Management Accounting Research & $\begin{array}{l}\text { International Journal of Production } \\
\text { Economics }\end{array}$ \\
\hline 3 & Harvard Business Review & $\begin{array}{l}\text { International Journal of Productivity and } \\
\text { Performance Management }\end{array}$ \\
\hline \multicolumn{3}{|c|}{ 2010-2018 } \\
\hline 1 & Accounting, Organization, and Society & Accounting, Organization, and Society \\
\hline 2 & Management Accounting Research & Management Accounting Research \\
\hline 3 & $\begin{array}{l}\text { International Journal of Operations and } \\
\text { Production Management }\end{array}$ & Harvard Business Review \\
\hline
\end{tabular}

\section{Discussion}

There has been a long debate about how accounting seemingly for years has struggled to find its identity and directions for future research, and among other reasons, the journals have been blamed for this development (Lukka 2010; Malmi 2010; McCarthy 2012; Merchant 2010). Even though this perhaps may be the case for 
sub-groups of accounting, for instance financial accounting or taxation, our data, however, indicate that the boundaries of management accounting research are perpetually on the move and difficult to grasp. Even though the journals that are defined in our context as management accounting and their cited sources are evolving, this is not enough to conclude that the researched topics are changing, yet it indicates a field that is not static. Then, one should conclude with utmost caution that accounting is a struggling discipline. Particularly, the huge number of articles being analysed supports this view.

On the other hand, the selection of search terms, and level of analysis, is not more 'neutral' than subjectively selecting journals. Only part of the research field will be analysed either way. We can convey Swanson's (2004) view that the definition may be somewhat arbitrary. Especially the search term performance measurement may be criticised. Performance is a term appearing within a wide variety of academic fields. However, the output seems reliable. Yet, the use of search terms relies on the premise that the term is included in the title, abstract, or as a keyword. This may not hold for every instance. We know that in Scopus 212 of the 593 articles indexed from MAR are missing. In WoS, 68 of the 242 indexed MAR articles are not returned by our search terms. It is most likely that they all should have been included. For many readers, the absence of Journal of Management Accounting Research (JMAR) and European Accounting Review (EAR) may raise amazement. But indeed, JMAR is not indexed in WoS, and EAR is only indexed from 2006 (and not 1992). Both journals, though, are present in the citation data, but not among the top cited journals. On the negative side, we have found bogus journals in the sample, such as Metalurgia International. It is also somewhat surprising to notice the appearance of journals such as Hydrocarbon Processing. The journal is serious, but maybe not top of mind when looking for management accounting research. This may be a shortcoming when it comes to the method applied, where search terms and database indices determine the outcome. However, an unsystematic check verifies a great number of relevant articles; i.e. management accounting techniques are applied within quite different scholarly fields.

In an even more globalized world, we can both expect convergence when it comes to use of constructs, as well as expansion of researched topics. Even more, the approach using English, even though being research's lingua franca, for all practical matters excludes substantial research published in other languages (Guthrie et al. 2019). This is confirmed by our study, particularly after 1980. One reason for this may be that $Z f B$ in WoS is indexed only from 1956 to 1980 (and not from 1924 until today). On the other hand, WoS has translated the articles' titles, something that most likely is the reason for the journal's appearance in the WoS ranking. Thus, the possible trend that can be read from the rankings decade by decade must be used with utmost caution. Therefore, we find it hard to speculate reasons to why TAR dominated 1960-1989 in WoS but it is not present as 'top' ranked from then on, and it is not present at all in Scopus.

Journal rankings are not consistent among countries (Guthrie et al. 2019), something that may prevent collaboration across countries as researchers have different incentives regarding where to publish. This is interesting as far as many universities 
promote internationalization, while at the same time they measure their employees according to rankings that may inhibit internationalization. Accounting knowledge production is socially constructed, and journal ranking is one significant part of the knowledge production system. Thus, quantitative journal rankings may not be more 'truthful' than qualitative ones. As Sangster (2015, p. 184) rhetorically puts it: 'You cannot judge a book by its cover, can you'? Therefore, discussing possible alternative approaches to ranking journals is important. As our findings indicate 'accounting is not a science but a ubiquitous practice very amenable to diverse social science investigation into its purposes, uses, and consequences' (Roberts 2018, p. 73). Thus, one may question whether citation data is suitable for evaluating the performance of academics. Notwithstanding, the mixed-methods approach can be useful when journals are subject to research. Quantitative analysis may offer ideas about which journals to include or not, while a qualitative approach may refine the suggested journals. This may account for both journal ranking as well as journal analyses.

Journal rankings based on citation data are also subject to much criticism: 'Citations should not and should never be the ultimate test of scholarship' (Guthrie et al. 2019 , p. 4). Even if most rankings rely on more than citations only, journal rankings are not fully transparent. ${ }^{3}$ Interestingly, both Thomson-Reuters and Elsevier emphasize that their metrics should be used with caution and combined with peer reviews. As Aksnes et al. (2019, p. 12) conclude, citations reflect scientific impact and relevance, but quality dimensions such as solidity/plausibility, originality, and the societal value of research cannot be measured by citations. With bibliometric indicators generally, and citations indicators specifically, ever on the rise in research evaluation, we find it crucial that researchers know the limitations of these analyses.

As discussed in the first part of this article, diversity is considered to be good for a scholarly field. If we convey this mindset to management accounting research, there are indications that this area is present in a variety of different journals. We also find indications that published articles draw on a variety of previous research. The indexes created indicate reference lists drawing on a variety of sources. Anyhow, perhaps most striking is the absence of three of the 'big six' accounting journals. Yet, these journals mainly publish financial accounting articles, which are beyond the scope of this article. Furthermore, a 'narrow' paradigm and a 'narrow' journal within this paradigm may create a substantial body of knowledge and thus contribute to the overall field. For instance, if a journal specializes in budgeting, this may add substantial knowledge to the area of budgeting and hence management accounting, and the budgeting research published may be homogenous as well as heterogenous. Yet, the flip side of diversity may be that an area may be too diversified to establish an accepted body of knowledge. On the other hand, for whom is that a problem? If too many journals look alike, this may inhibit opportunities for understanding social objects such as accounting from different perspectives, and thus stimulate superficiality (Gendron 2008). Moreover, society is richer when knowledge is diversified (Gendron 2018). Nevertheless, we acknowledge the fact that one person's perception of diversity is depending on the view initially held (Salterio 2018).

\footnotetext{
${ }^{3}$ See for instance https://www.elsevier.com/authors/journal-authors/measuring-a-journals-impact and https://clarivate.com/products/journal-citation-reports/.
} 


\section{Closing remarks}

This article was partly motivated by the fact that journals used for different analyses, often are characterized as supreme without further explanation. To make an empirical contribution, we have searched three databases and analysed more than 1 million entries in reference lists. By doing this, we sketch a picture of journals publishing and influencing research under the umbrella of management accounting and add knowledge to the area of management accounting as represented by the journals. To answer our first question. Within the field of management accounting, AOS and $M A R$ are the most cited journals in WoS as well as in Scopus. Thus, we have found that this bibliometric analysis confirms previous studies. In this way, a priori reasoning is supported by a large amount of data. Yet, only three of the 'big six' are represented at the top. We also find a large diversity when it comes to both input and output in management accounting. Regarding our second question, we raise some serious concerns and caveats about using citation data based on these databases, and GS in particular must be used with the utmost caution. The databases are not exhaustive when it comes to journals, indexing is not standardised, and bogus journals are included. As such, the use of databases offers neither complete nor accurate ranking.

This study, of course, has its limitations. Even though the approach does not restrict the selection of journals to 'conventional wisdom', we do not control for the number of volumes (The Accounting Review dates to 1926) or the publication frequency per year (for instance, The Journal of the American Medical Association is published 48 times per year). Our study only provides a partial overview of the research field; research may be unintentionally excluded due to limited indexing and the selection of keywords - and, for the same reasons, irrelevant documents are part of the analysis. Last, but not least, we acknowledge that the selection of databases and search terms, as well as the use of citations as an indicator, are all subject to author bias.

Despite these limitations, however, our study offers potential insights into the use of citation data as a source for rankings. This study also offers further understanding of issues regarding the use of large databases and the troublesome exercise of grasping a scholarly field through search terms. A next step can be to go deeper into the concept of diversity when it comes to topics, methods, theories, and so on based on large data sets. In addition, the application of management accounting in other fields, such as engineering, medicine, informatics and sustainable production, as well as its inspiration from research in languages other than English, could open avenues for further research on the transfer of knowledge in the field of management accounting research.

Open Access This article is distributed under the terms of the Creative Commons Attribution 4.0 International License (http://creativecommons.org/licenses/by/4.0/), which permits unrestricted use, distribution, and reproduction in any medium, provided you give appropriate credit to the original author(s) and the source, provide a link to the Creative Commons license, and indicate if changes were made. 


\section{References}

Aguillo, I. (2012). Is Google Scholar useful for bibliometrics? A webometric analysis. Scientometrics, 91(3), 343-351.

Aksnes, D. W., Langfeldt, L., \& Wouters, P. (2019). Citations, citation indicators, and research quality: An overview of basic concepts and theories. SAGE Open, 9(1), 1-17.

Annisette, M., Cooper, C., \& Gendron, Y. (2018). Editorial: The question of research diversity in "top" accounting journals. Critical Perspectives on Accounting, 51, 1-3.

Ax, C., \& Bjørnenak, T. (2007). Management accounting innovations: origins and diffusion. In T. Hopper, D. Northcott, \& R. W. Scapens (Eds.), Issues in management accounting (pp. 357-376). Harlow: Prentice Hall.

Baldvinsdottir, G., Mitchell, F., \& Nørreklit, H. (2010). Issues in the relationship between theory and practice in management accounting. Management Accounting Research, 21(2), 79-82.

Beets, S., Kelton, A., \& Lewis, B. (2015). An assessment of accounting journal quality based on departmental lists. Scientometrics, 102(1), 315-332.

Berens, W. (2014). A broad field of management control. Journal of Management Control, 24(4), 299-300.

Berg, T. (2015). A compass for teaching enterprise governance. Accounting Education: An International Journal, 24(6), 559-563.

Binder, C., \& Schäffer, U. (2005). Die Entwicklung des Controllings von 1970 bis 2003 im Spiegel von Publikationen in deutschsprachigen Zeitschriften. Die Betriebswirtschaft, 65(6), 603-626.

Bonner, S. E., Hesford, J. W., van der Stede, W. A., \& Young, S. M. (2006). The most influential journals in academic accounting. Accounting, Organizations and Society, 31(7), 663-685.

Borgman, C. L. (2007). Scholarship in the digital age: Information, infrastructure, and the internet. Cambridge: MIT Press.

Bourne, M., Melnyk, S., \& Bititci, U. S. (2018). Performance measurement and management: Theory and practice. International Journal of Operations and Production Management, 38(11), 2010-2021.

Brown, L. D., \& Gardner, J. C. (1985). Using citation analysis to assess the impact of journals and articles on contemporary accounting research (CAR). Journal of Accounting Research, 23(1), 84-109.

Card, D., \& DellaVigna, S. (2013). Nine facts about top journals in economics. Journal of Economic Literature, 51(1), 144-161.

Chenhall, R. H. (2003). Management control systems design within its organizational context: Findings from contingency-based research and directions for the future. Accounting, Organizations and Society, 28(2-3), 127-168.

Cronin, B. (1984). The citation process: The role and significance of citations in scientific communication. London: Taylor Graham.

Endenich, C., \& Trapp, R. (2018). Signalling effects of scholarly profiles-The editorial teams of North American accounting association journals. Critical Perspectives on Accounting, 51, 4-23.

Euske, K. J., Hesford, J. W., \& Malina, M. A. (2011). A social network analysis of the literature on management control. Journal of Management Accounting Research, 23(1), 259-283.

Evans, L. (2010). Observations on the changing language of accounting. Accounting History, 15(4), 439-462.

Ferreira, A., \& Otley, D. (2009). The design and use of performance management systems: An extended framework for analysis. Management Accounting Research, 20(9), 263-282.

Fleck, C. (2013). The impact factor fetishism. European Journal of Sociology, 54(2), 327-356.

Franco-Santos, M., \& Otley, D. (2018). Reviewing and theorizing the unintended consequences of performance management systems. International Journal of Management Reviews, 20(3), 696-730.

Garfield, E. (1979). Is citation analysis a legitimate evaluation tool? Scientometrics, 1(4), 359-375.

Gendron, Y. (2008). Constituting the academic performer: The spectre of superficiality and stagnation in academia. European Accounting Review, 17(1), 97-127.

Gendron, Y. (2018). On the elusive nature of critical (accounting) research. Critical Perspectives on Accounting, 50(1), 1-12.

Günther, T. W. (2013). Conceptualisations of 'controlling' in German-speaking countries: analysis and comparison with Anglo-American management control frameworks. Journal of Management Control, 23(4), 269-290. 
Günther, T. W., \& Heinicke, A. (2019). Relationships among types of use, levels of sophistication, and organizational outcomes of performance measurement systems: The crucial role of design choices. Management Accounting Research, 42(1), 1-25.

Guthrie, J., Parker, L. D., Dumay, J., \& Milne, M. J. (2019). What counts for quality in interdisciplinary accounting research in the next decade: A critical review and reflection. Accounting, Auditing and Accountability Journal, 32(1), 2-25.

Harzing, A. W. (2007) Publish or Perish. Accessed October 15th 2018. https://harzing.com/resources/ publish-or-perish.

Harzing, A. W., \& Alakangas, S. (2016). Google Scholar, Scopus and the Web of Science: A longitudinal and cross-disciplinary comparison. Scientometrics, 106(2), 787-804.

Herschung, F., Mahlendorf, M. D., \& Weber, J. (2018). Mapping quantitative management accounting research. Journal of Management Accounting Research, 30(1), 73-141.

Hesford, J. W., Lee, S. H., van der Stede, W. A., \& Young, S. M. (2007). Management accounting: A bibliographic study. In C. S. Chapman, A. G. Hopwood, \& M. D. Shields (Eds.), Handbook of management accounting research (Vol. 1, pp. 3-26). Amsterdam: Elsevier.

Hopwood, A. G. (2008). Management accounting research in a changing world. Journal of Management Accounting Research, 20, 3-13.

Horngren, C. T. (1982). Cost accounting: A managerial emphasis. Englewood Cliffs: Prentice-Hall.

Horngren, C. T., Foster, G. M., \& Datar, S. M. (2005). Cost accounting: A managerial emphasis (12th ed.). Englewood Cliffs: Prentice-Hall.

Jacsó, P. (2005). Google Scholar: The pros and the cons. Online Information Review, 29(2), 208-214.

Jacsó, P. (2006). Deflated, inflated and phantom citation counts. Online Information Review, 30(3), 297-309.

Jacsó, P. (2010). Metadata mega mess in Google Scholar. Online Information Review, 34(1), 175-191.

Kärki, R., \& Kortelainen, T. (1998). Introduktion till bibliometri (Vol. 41). Espoo: NORDINFO.

Lachmann, M., Trapp, I., \& Trapp, R. (2017). Diversity and validity in positivist management accounting research-A longitudinal perspective over four decades. Management Accounting Research, 34(1), 42-58.

Lipsman, N., \& Lozano, A. M. (2011). The most cited works in major depression: The 'Citation classics'. Journal of Affective Disorders, 134(1-3), 39-44.

Luft, J., \& Shields, M. D. (2007). Mapping management accounting: Graphics and guidelines for theoryconsistent empirical research. In C. S. Chapman, A. Hopwood, \& M. D. Shields (Eds.), Handbook of management accounting research (Vol. 1, pp. 27-95). Amsterdam: Elsevier.

Lukka, K. (2010). The roles and effects of paradigms in accounting research. Management Accounting Research, 21(2), 110-115.

Lukka, K., \& Kasanen, E. (1996). Is accounting a global or a local discipline? Evidence from major research journals. Accounting, Organizations and Society, 21(7), 755-773.

Macdonald, S., \& Kam, J. (2011). The skewed few: People and papers of quality in management studies. Organization, 18(4), 467-475.

Macroberts, M., \& Macroberts, B. (1989). Problems of citation analysis: A critical review. Journal of the American Society for Information Science, 40, 342-349.

Malmi, T. (2010). Reflections on paradigms in action in accounting research. Management Accounting Research, 21(2), 121-123.

Malmi, T. (2016). Managerialist studies in management accounting: 1990-2014. Management Accounting Research, 31(1), 31-44.

McCarthy, W. E. (2012). Accounting craftspeople versus accounting seers: Exploring the relevance and innovation gaps in academic accounting research. Accounting Horizons, 26(4), 833-843.

Merchant, K. A. (2010). Paradigms in accounting research: A view from North America. Management Accounting Research, 21(2), 116-120.

Meyer, M., Schäffer, U., \& Gmür, M. (2008). Transfer und Austausch von Wissen in der AccountingForschung: Eine Zitations-und Kozitationsanalyse englischsprachiger Accounting-Journals 19902004. ZFBF: Schmalenbachs Zeitschrift für Betriebswirtschaftliche Forschung, 60(2), 153-181.

Meyer, M., Waldkirch, R. W., Duscher, I., \& Just, A. (2018). Drivers of citation: An analysis of 'top' accounting journals. Critical Perspectives on Accounting, 51, 24-46.

Moed, H. (2005). Citation analysis in research evaluation (Vol. 9). Dordrecht: Springer.

Moser, D. V. (2012). Is accounting research stagnant? Accounting Horizons, 26(12), 845-850.

Oler, D. K., Oler, M. J., Skousen, C. J., \& Talakai, J. (2016). Has concentration in the top accounting journals changed over time? Accounting Horizons, 30(1), 63-78. 
Raffournier, B., \& Schatt, A. (2010). Is European accounting research fairly reflected in academic journals? An investigation of possible non-mainstream and language barrier biases. European Accounting Review, 19(1), 161-190.

Roberts, R. W. (2018). We can do so much better: Reflections on reading "signaling effects of scholarly profiles-The editorial teams of North American Accounting Association Journals. Critical Perspectives on Accounting, 51, 70-77.

Salterio, S. E. (2015). Barriers to knowledge creation in management accounting research. Journal of Management Accounting Research, 27(1), 151-170.

Salterio, S. E. (2018). Signaling effects of scholarly profiles-The editorial teams of North American accounting association journals: A personal perspective. Critical Perspectives on Accounting, 51, 78-83.

Samuel, S. (2018). A conceptual framework for teaching management accounting. Journal of Accounting Education, 44, 25-34.

Sangster, A. (2015). You cannot judge a book by its cover: The problems with journal rankings. Accounting Education: An International Journal, 24(3), 175-186.

Scapens, R. W. (2014). My final editorial. Management Accounting Research, 25(4), 245-250.

Schäffer, U. (2013). Management accounting research in Germany: From splendid isolation to being part of the international community. Journal of Management Control, 23(4), 291-309.

Schäffer, U., Binder, C., \& Gmür, M. (2006). Structure and development of research on controllingA citation analysis paper on controlling in German speaking journals from 1970 through 2003. Zeitschrift für Betriebswirtschaft, 76(4), 395-440.

Strauss, E., \& Zecher, C. (2013). Management control systems: A review. Journal of Management Control, 23(4), 233-268.

Stuart, D. (2014). Web metrics for library and information professionals. London: Facet Publishing.

Summers, S. L., \& Wood, D. A. (2017). An evaluation of the general versus specialist nature of top accounting journals. Accounting Horizons, 31(2), 105-124.

Swanson, E. P. (2004). Publishing in the majors: A comparison of accounting, finance, management, and marketing. Contemporary Accounting Research, 21(1), 223-255.

ter Bogt, H., \& van Helden, J. (2012). The practical relevance of management accounting research and the role of qualitative methods therein: The debate continues. Qualitative Research in Accounting and Management, 9(3), 265-273.

Tessier, S., \& Otley, D. (2012). From management controls to the management of controls. Accounting, Auditing and Accountability Journal, 25(5), 776-805.

White, H. D. (2012). Citation analysis. In M. J. Bates \& M. N. Maack (Eds.), Encyclopedia of library and information sciences (Vol. 3, pp. 1012-1026). Oxford: Taylor \& Francis.

Wilkinson, D. (2016). The BIG difference between the Oxford review and the Harvard Business review. https://www.oxford-review.com/the-big-difference-between-the-oxford-review-and-the-harvardbusiness-review-1/. Accessed 7th November 2018.

Publisher's Note Springer Nature remains neutral with regard to jurisdictional claims in published maps and institutional affiliations. 